\title{
MDM2 Inhibitor
}

National Cancer Institute

\section{Source}

National Cancer Institute. MDM2 Inhibitor. NCI Thesaurus. Code C162996.

Any agent that binds to mouse double minute 2 (human double minute 2 homolog; MDM2; HDM2) and prevents the interaction with the tumor suppressor protein p53, with potential antineoplastic activity. 